\title{
Generalized fractional midpoint type inequalities for co-ordinated convex functions
}

\author{
Fatih HEZENCI ${ }^{1}$, Hüseyin BUDAK ${ }^{2}$, Hasan KARA ${ }^{1}$, and Mehmet Zeki Sarikaya ${ }^{3}$ \\ ${ }^{1}$ Düzce Üniversitesi \\ ${ }^{2}$ Duzce University \\ ${ }^{3}$ Duzce Universitesi
}

November 19, 2021

\begin{abstract}
In this research paper, we investigate generalized fractional integrals to obtain midpoint type inequalities for the co-ordinated convex functions. First of all, we establish an identity for twice partially differentiable mappings. By utilizing this equality, some midpoint type inequalities via generalized fractional integrals are proved. We also show that the main results reduce some midpoint inequalities given in earlier works for Riemann integrals and Riemann-Liouville fractional integrals. Finally, some new inequalities for $\$ \mathrm{k} \$$-Riemann-Liouville fractional integrals are presented as special cases of our results.
\end{abstract}

\section{Hosted file}

Fractional Hermite Hadamard's Type Inequality for 2 Variable.pdf available at https: //authorea.com/users/446994/articles/546101-generalized-fractional-midpoint-typeinequalities-for-co-ordinated-convex-functions

\section{Hosted file}

Fractional Hermite Hadamard's Type Inequality for 2 Variable.tex available at https: //authorea.com/users/446994/articles/546101-generalized-fractional-midpoint-typeinequalities-for-co-ordinated-convex-functions 